\title{
Inhibition of rat alveolar macrophage phagocytic function by a Pseudomonas cepacia lipase
}

\author{
D. C. STRAUS, MIRIAM K. LONON* and J. C. HUTSON†
}

Departments of Microbiology and "Anatomy and Cell Biology, Texas Tech University Health Sciences Center, Lubbock, Texas 79430 and $\dagger$ Department of Microbiology, Miami University, Oxford, Ohio 45056, USA

\begin{abstract}
Summary. The effects of purified Pseudomonas cepacia lipase on rat pulmonary alveolar function and morphology were examined. Lipase $(2.5-20 \mu \mathrm{g} / \mathrm{ml})$ adversely effected the phagocytic function of rat pulmonary alveolar macrophages in a dose-dependent manner. The lipase itself was not directly cytotoxic to these cells. Alveolar macrophages, in the absence of lipase, phagocytosed $c .35 \%$ of a given population of opsonised P. cepacia in $30 \mathrm{~min}$ when the ratio of bacteria:phagocyte was 10:1. Phagocytosis of $P$. cepacia by rat pulmonary alveolar macrophages was significantly reduced when the cells were either pre-incubated with the lipase or when phagocytosis occurred in the presence of the lipase. This was confirmed by transmission electronmicroscopy. These functional changes were associated with marked alterations of the macrophage morphology. Scanning electronmicroscopy showed that macrophages exposed to the $P$. cepacia lipase had fewer specialised surface structures and did not spread on plastic surfaces as well as untreated macrophages. The effects of the lipase were lost after heat inactivation, which indicates that the effects of the $P$. cepacia lipase were due to its enzymic activity. These results suggest that, if sufficient quantities of the enzyme are produced in vivo, lipase may be an important virulence factor for $P$. cepacia, allowing the organism to evade phagocytic cells.
\end{abstract}

\section{Introduction}

Pseudomonas cepacia was first described by Burkholder in $1950^{1}$ as the causative agent of bacterial onion bulb rot. At first this organism was thought to be only a phytopathogen, but it is now recognised as an important cause of opportunist infection in man. ${ }^{2,3}$ It has recently received a great deal of attention because of its association with fatal pulmonary infections in patients with cystic fibrosis. ${ }^{4-6}$

Relatively little is known about the virulence factors of this organism. McKevitt and Woods ${ }^{7}$ demonstrated that $P$. cepacia produces an appreciable number of extracellular products including gelatinase, haemolysin, protease and lipase. Straus et al.$^{8,9}$ demonstrated the production of a material they called the extracellular toxic complex (ETC) that was composed of capsular polysaccharide (CPS), lipopolysaccharide (LPS) and protein. This material caused extensive pulmonary pathology when deposited in the lungs of experimental animals. Lonon et al. ${ }^{10}$ recently characterised a lipase from $P$. cepacia and examined its toxicity in tissue culture and in vivo. The same authors showed that of $10 \mathrm{P}$. cepacia strains examined, all produced an immunologically similar lipase. ${ }^{11}$

Extracellular lipase production by $P$. cepacia has been studied with regard to physical, chemical and enzymic properties, ${ }^{10,11}$ but the role of lipase in infections has not been examined. Rollof et al. ${ }^{12}$ recently demonstrated that an extracellular lipase produced by Staphylococcus aureus reduced phagocytic killing of the homologous organisms by granulocytes pre-incubated with the lipase, in a dosedependent manner. Therefore, we examined the lipase produced by $P$. cepacia to find out whether it had a similar effect on pulmonary alveolar macrophages.

\section{Materials and methods}

\section{Enzyme}

Lipase from $P$. cepacia strain 90ee was purified as described previously. ${ }^{10}$ The lipase was homogeneous when tested by SDS-PAGE, yielding a single Coomassie Blue-staining band with an apparent $M_{r}$ of $30 \mathrm{kDa}$. Gel chromatography on Sephadex G-200 also showed homogeneity. The lipase activity was c. $4387 \times 10^{-3}$ units $/ \mu \mathrm{g}$ of protein, with Tween 20 as substrate ( 1 unit of lipase activity was defined as that amount of enzyme that, after $2 \mathrm{~h}$ under the conditions of the assay, resulted in an increase of optical density at $400 \mathrm{~nm}$ of 0.01 ). The purified lipase preparation was dialysed extensively against Dulbecco's Modified 
Eagles Medium (Sigma) containing bovine calf serum $10 \%$ (Hyclone, Logan, UT, USA) (DMEMS) and sterilised by filtration before use in phagocytic assays. Inactivated lipase was prepared by heating $\left(100^{\circ} \mathrm{C}\right.$, $120 \mathrm{~min}$ ) and the activity was checked at intervals to exclude reactivation.

\section{Bacteria}

P. cepacia strain 90ee (Pc 90ee) was used for all experiments. It was obtained from J. D. Klinger, Rainbow Babies and Children's Hospital, Cleveland, $\mathrm{OH}$, and was maintained frozen in tryptic soy broth with glycerol $20 \%$ at $-70^{\circ} \mathrm{C}$. Cultures were grown for $24 \mathrm{~h}$ at $37^{\circ} \mathrm{C}$ with shaking at $200 \mathrm{rpm}$ to an $\mathrm{OD}_{540}$ of c. $1 \cdot 0$. This represented $c .8 \times 10^{8} \mathrm{cfu} / \mathrm{ml}$. Bacteria were collected by centrifugation, washed three times in sterile phosphate-buffered saline (PBS) and diluted appropriately in Minimal Essential Medium (MEM; Sigma) before use.

\section{Isolation of alveolar macrophages}

Pulmonary alveolar macrophages (PAM) were obtained from the lungs of pentobarbitol-anaesthetised male Wistar rats. Lungs were lavaged five times intratracheally with $8 \mathrm{ml}$ of saline. Cells were recovered by centrifugation at $800 \mathrm{~g}$ for $10 \mathrm{~min}$. Macrophages were suspended in DMEMS and placed in microtitration-plate wells in $200 \mu$ l amounts containing $7 \times 10^{4}$ cells and maintained in a water-saturated atmosphere of air $95 \%$ and $\mathrm{CO}_{2} 5 \%$. Non-adherent cells were removed by five vigorous washings with culture medium.

\section{Opsonophagocytic assay}

Bacteria were pre-treated twice for $30 \mathrm{~min}$ at $25^{\circ} \mathrm{C}$ with $0.5 \mathrm{ml}$ of fresh rat serum obtained on the day of use as a source of complement, and then washed three times in sterile PBS. Centrifugation of bacteria during these treatments was performed in a Beckman J2-21 centrifuge at $12000 \mathrm{~g}$ at $4^{\circ} \mathrm{C}$ for $30 \mathrm{~min}$. Bacteria were added $\left(7 \times 10^{5} \mathrm{cfu}\right.$ in $\left.10 \mu \mathrm{l}\right)$ to the macrophage cultures at a ratio of 10 bacteria to one macrophage. Cells were incubated for $5-120 \mathrm{~min}$ at $37^{\circ} \mathrm{C}$ in a $\mathrm{CO}_{2} 5 \%$ environment. Assay medium was collected and dilutions in PBS were plated on brain heart infusion agar. Plates were incubated for $48 \mathrm{~h}$ at $37^{\circ} \mathrm{C}$. Colonies were counted to determine the titre as colony forming units $(\mathrm{cfu}) / \mathrm{ml}$. Results were calculated as follows:

Percentage uptake $=$

$$
\frac{\mathrm{cfu} / 10 \mu \mathrm{l}(\mathrm{x} \text { time })-\mathrm{cfu} / 10 \mu \mathrm{l}(0 \mathrm{time})}{\mathrm{cfu} / 10 \mu \mathrm{l}(0 \text { time })} \times 100
$$

where $\mathrm{x}$ equals the time in min that the assay was incubated. All assays were run in triplicate and were repeated at least three times. The results presented were obtained from a representative experiment.

\section{Electronmicroscopy}

The macrophages were prepared as described above for the opsonophagocytic studies. For transmission electronmicroscopy (TEM), c. $1 \times 10^{7}$ macrophages were incubated with $1 \times 10^{8} \mathrm{Pc} 90 \mathrm{ee}$ in $1 \mathrm{ml}$ of DMEMS with and without active lipase $20 \mu \mathrm{g} / \mathrm{ml}$. For scanning electronmicroscopy (SEM), $1 \times 10^{7}$ macrophages were incubated in $1 \mathrm{ml}$ of DMEMS with and without active lipase $20 \mu \mathrm{g} / \mathrm{ml}$. After $30 \mathrm{~min}$, the macrophages were fixed in glutaraldehyde $3 \%$ in $0.1 \mathrm{M}$ sodium cacodylate buffer, $\mathrm{pH} 7 \cdot 3$, for $1 \mathrm{~h}$ at room temperature. The samples were then post-fixed in osmium textroxide $1 \%$ and prepared for ultrastructural analysis by standard methods. ${ }^{13}$ Since it has been shown that lipase from one bacterial species $(S$. aureus) markedly alters the surface structure of human granulocytes, ${ }^{12}$ we evaluated the effect of $P$. cepacia lipase on the surface of rat PAM. To determine the percentage of macrophages in a population that were "spread out" on a plastic surface, 20 separate fields for each preparation were examined by SEM by standard procedures. ${ }^{13}$ The percentage of spreading (spread cells/total cells) for each field was calculated and the Mann-Whitney test was used to determine whether lipase treatment caused a significant change in the cell population.

\section{Serum and macrophage viability}

Undiluted fresh rat serum was used in all bacterial opsonisation experiments. The viability of the rat PAM was tested by trypan blue dye exclusion. Macrophages were pre-incubated with lipase $20 \mu \mathrm{g} / \mathrm{ml}$ for $30 \mathrm{~min}$ at $37^{\circ} \mathrm{C}$ as well as in DMEMS alone and were examined for viability by light microscopy.

\section{Results}

\section{Temporal phagocytosis of opsonised Pc 90ee by rat $P A M$}

When Pc 90ee was opsonised by undiluted fresh rat serum and exposed to rat PAM at a ratio of 10:1, phagocytosis occurred rapidly (fig. 1). After $5 \mathrm{~min}, c$. $11 \%$ of the bacteria were phagocytosed. Phagocytosis reached a maximum of $34 \%$ after incubation for $15 \mathrm{~min}$ and remained virtually unchanged for up to $2 \mathrm{~h}$.

\section{Effect of Pc 90ee lipase on rat PAM phagocytic killing}

Pre-incubation of rat PAM with Pc 90ee lipase was associated with a dose-dependent decrease in phagocytosis of Pc 90ee (fig. 2). Exposure to lipase for $15 \mathrm{~min}$ at $2.5 \mu \mathrm{g} / \mathrm{ml}$ reduced Pc 90ee uptake to $22 \%$, macrophages pre-incubated with DMEMS alone retained their phagocytic capacity of $32 \%$. Macrophages preincubated with lipase $5 \mu \mathrm{g} / \mathrm{ml}$ had their phagocytic 


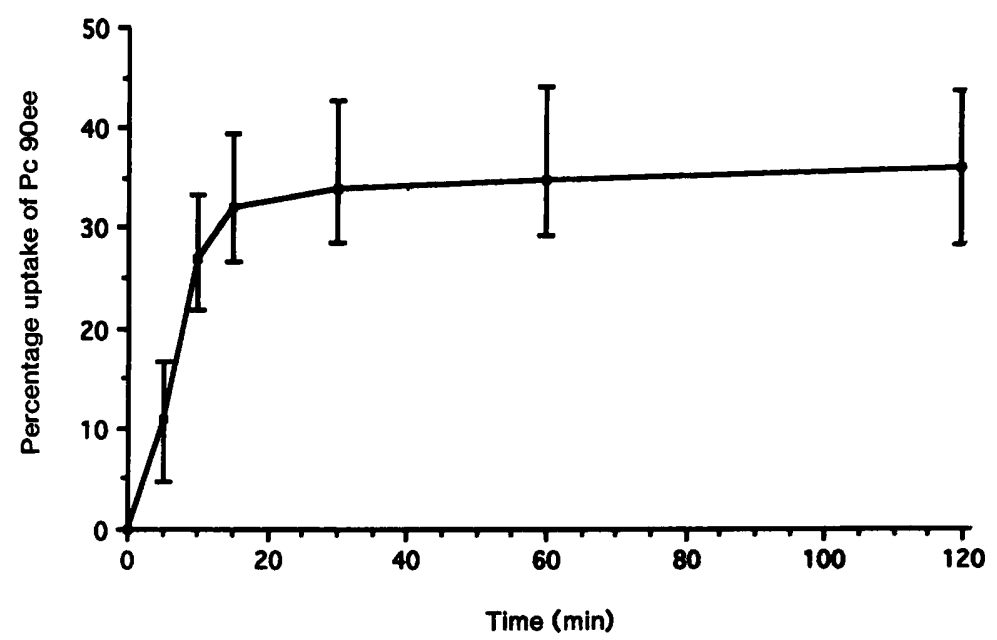

Fig. 1. Phagocytosis by rat PAM of $P$. cepacia 90 ee opsonised in undiluted fresh rat serum. Percentage uptake was determined after $5,10,15$, 30,60 and $120 \mathrm{~min}$.

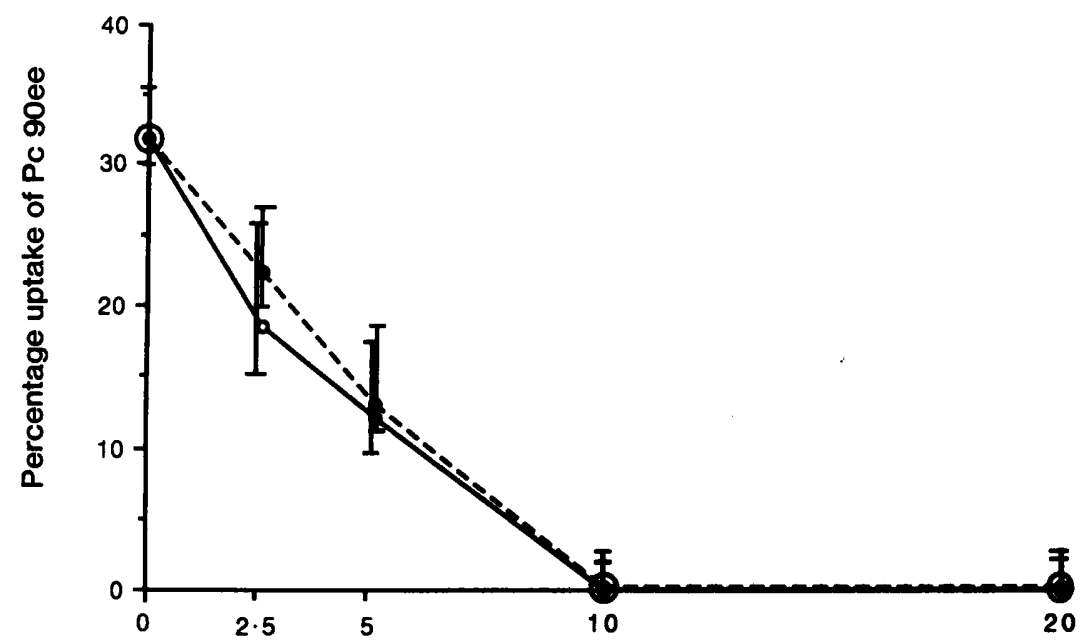

Lipase concentration $(\mu \mathrm{g} / \mathrm{ml})$

Fig. 2. Effects of pre-treatment with lipase or concomitant exposure to lipase on phagocytic killing by rat PAM. After pre-incubation with various concentrations of lipase $(--)$ ) or concomitant exposure to lipase and bacteria $(\mathrm{O}-\mathrm{O})$, rat PAM were incubated with opsonised $P$. cepacia 90ee. Bacterial uptake was determined after $30 \mathrm{~min}$ at $37^{\circ} \mathrm{C}$ in a $\mathrm{CO}_{2} 5 \%$ environment.

capability reduced to $12.5 \%$. Macrophages preincubated with Pc 90 ee lipase 10 or $20 \mu \mathrm{g} / \mathrm{ml}$ for 15 min were essentially unable to phagocytose Pc 90ee.

A similar effect was noted when the lipase was added to the phagocytic assay concomitant with the opsonised bacteria. Fig. 2 shows that when Pc 90ee lipase $2.5 \mu \mathrm{g} / \mathrm{ml}$ was added to the phagocytic assays along with the opsonised bacteria, phagocytosis by rat PAM was reduced from $32 \%$ to $c$. $18 \%$. When the amount of lipase added was increased to $5 \mu \mathrm{g} / \mathrm{ml}$, phagocytosis was decreased to $11.8 \%$. The addition of lipase 10 or $20 \mu \mathrm{g} / \mathrm{ml}$ to the phagocytic assay along with the opsonised Pc $90 \mathrm{ee}$ totally prevented phagocytosis. The lipase $(20 \mu \mathrm{g} / \mathrm{ml})$ had no effect on the viability of the cells as determined by trypan blue dye exclusion. More than $95 \%$ of the macrophages remained viable after exposure to lipase for $30 \mathrm{~min}$. Moreover, lipase inactivated by heat had no effect on the phagocytic capability of the rat PAM when the concentrations described above were used (data not shown).

\section{Transmission electronmicroscopy}

Fig. 3a shows a portion of a rat PAM that had been exposed to opsonised Pc 90ee for $30 \mathrm{~min}$. Numerous phagocytosed Pc 90ee cells are visible inside the macrophage. Fig. $3 \mathrm{~b}$ shows a higher magnification of phagocytosed P. cepacia inside a rat PAM. Fig. 3c illustrates a TEM of Pc 90ee cells that have not been phagocytosed. The size and shape of these bacteria are very similar to phagocytosed $P$. cepacia inside rat PAM.

\section{Scanning electronmicroscopy}

Because TEM studies indicated that rat PAM treated with lipase were incapable of phagocytosing Pc 90ee, we performed SEM to observe better macrophage surfaces. Pre-treatment with Pc 90ee lipase greatly affected macrophage morphology. The normal appearance of rat PAM incubated in DMEMS alone can be seen in fig. 4. These rat PAM appear to be in the 

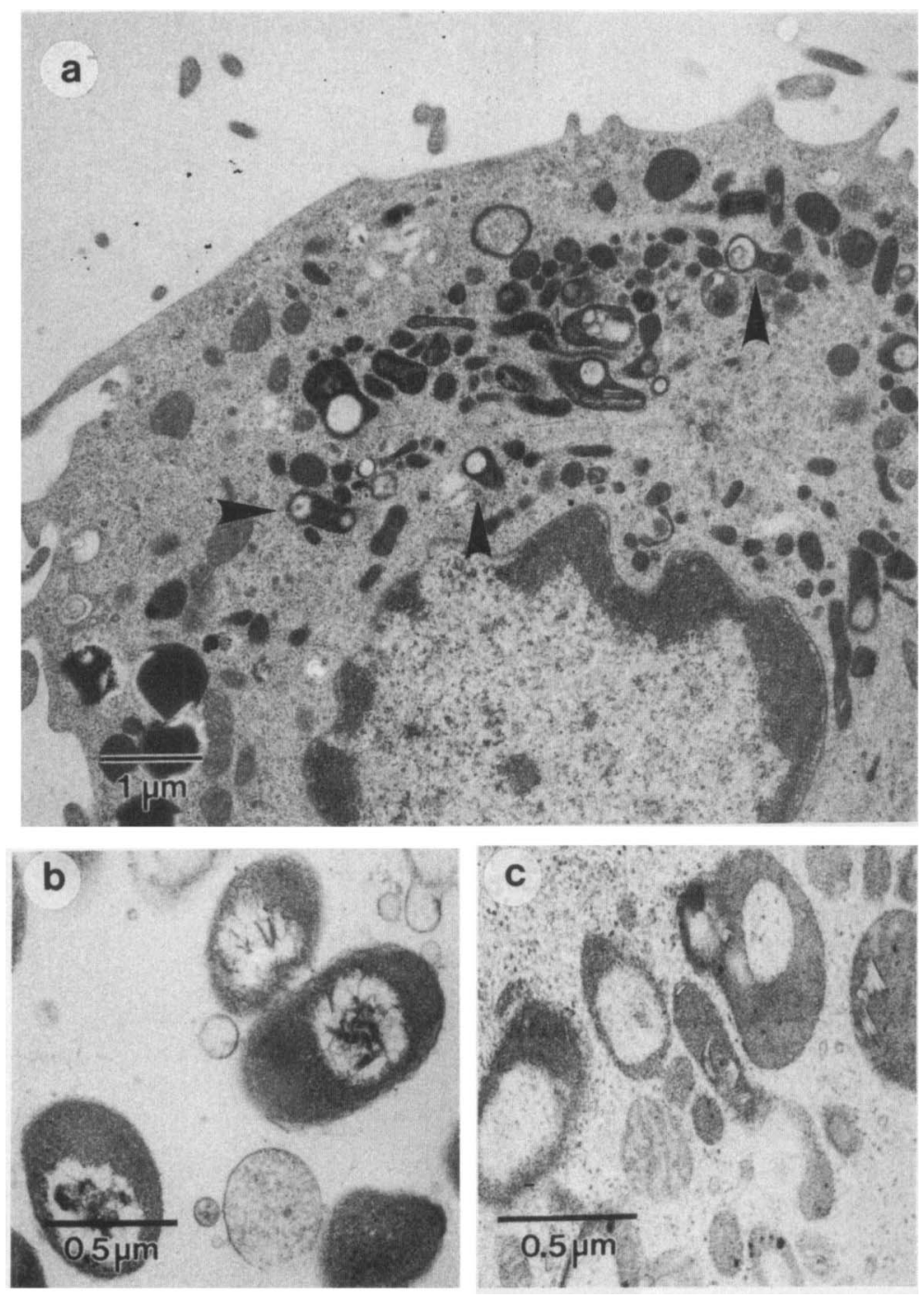

Fig. 3. TEM of a rat PAM incubated in DMEMS without lipase. (a) The macrophages were exposed to $P$. cepacia $90 \mathrm{ee}$ for $30 \mathrm{~min}$ and numerous bacteria (arrows) were internalised $(\times 13750)$. (b) A section of a rat PAM containing internalised $P$. cepacia $90 \mathrm{ee}(\times 68750)$. (c) A pellet of $P$. cepacia 90ee treated as described for $(b)(\times 44000)$.

process of spreading on the plastic surface. However, after treatment with Pc 90ee lipase $20 \mu \mathrm{g} / \mathrm{ml}$, most macrophages remained round (fig. 5), which is their shape when they are isolated initially from the rat lung. Treated macrophages exhibited a morphology that clearly differed from the normal complex shape of the untreated rat PAM with its numerous pseudopodia, microvilli and other projections. Indeed, when 20 different fields of lipase-treated and normal rat PAM were examined by SEM, it was clear that the lipasetreated cells were significantly less capable of "spreading out" than the untreated rat PAM. The table shows that in an untreated rat PAM population, after incubation for $30 \mathrm{~min}$ at $37^{\circ} \mathrm{C}, c .64 \%$ of the cells were beginning to spread out on the plastic surface. However, when lipase $20 \mu \mathrm{g} / \mathrm{ml}$ was present, only $32 \%$ of the macrophages had begun to spread after incubation for $30 \mathrm{~min}$.

\section{Discussion}

Many micro-organisms produce extracellular enzymes that are lipolytic. Whereas it has been specu- lated that the physiological role of extracellular lipases produced by bacteria is probably nutritional, ${ }^{10}$ the hypothesis has also been put forward that the extraordinarily large amounts of lipase excreted by some strains may indicate that the enzyme performs other functions. ${ }^{12}$ For example, Rollof et al..$^{12}$ demonstrated that phagocytic killing of $S$. aureus by human granulocytes pre-incubated with $S$. aureus lipase was reduced in a dose-dependent manner. Furthermore, Jaeger $e t$ $a l .^{14}$ have shown recently that an extracellular lipase of $P$. aeruginosa inhibited chemiluminescence by human peripheral blood monocytes. This inhibitory effect was dose dependent and was abolished by heating the enzyme at $100^{\circ} \mathrm{C}$. These studies, together with our findings that demonstrate that $P$. cepacia lipase decreased phagocytic function of rat PAM, are consistent with the hypothesis that lipase may play a role in pathogenesis.

The $P$. cepacia lipase appears to exert its antiphagocytic effect on rat PAM by affecting the cell surface. Normal rat PAM tend to form pseudopodia and "spread out" on the plastic surface. Rat PAM exposed to lipase $20 \mu \mathrm{g} / \mathrm{ml}$ for 30 min show greatly reduced 


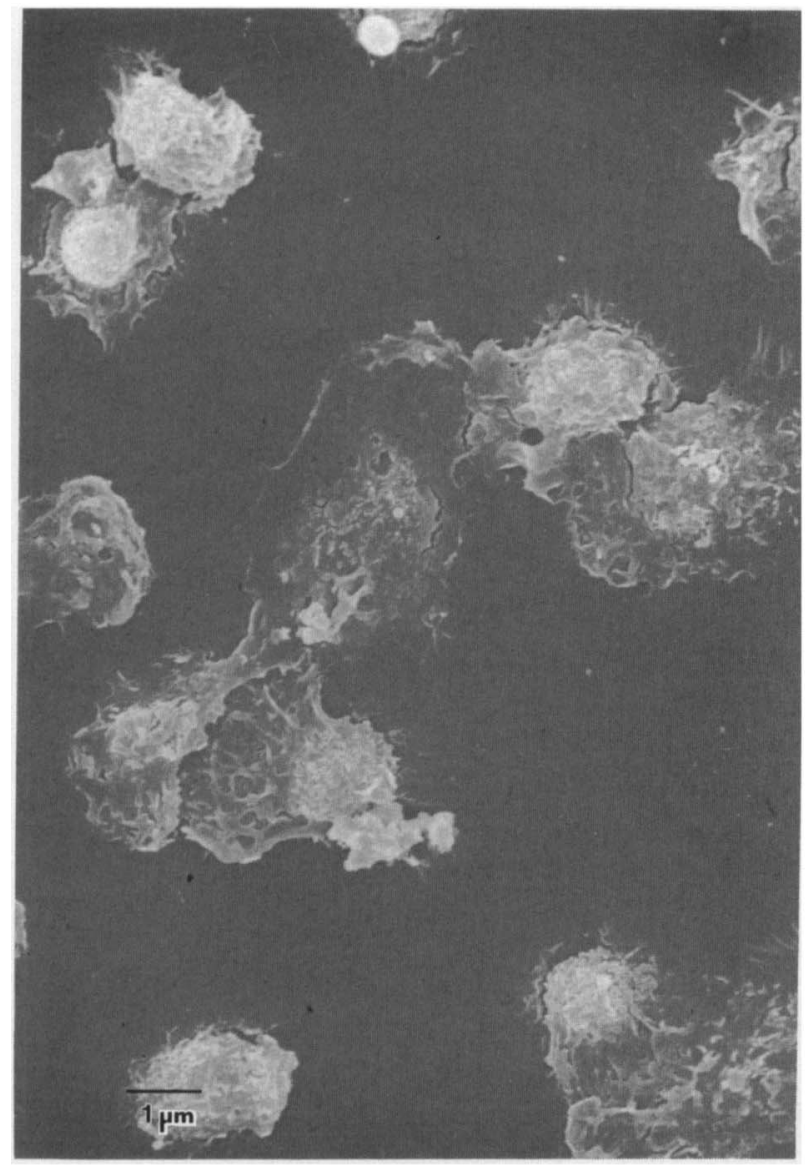

Fig. 4. SEM of rat PAM incubated in DMEMS without lipase.

pseudopodia and diminished "spreading." Rollof $e t$ al. obtained similar results: $:^{12}$ they demonstrated that pre-treatment with $S$. aureus lipase greatly affected human granulocyte morphology. After pre-incubation with $S$. aureus lipase $12 \mu \mathrm{g} / \mathrm{ml}$, most of the granulocytes had denuded, flat surfaces. This was in marked contrast to the surface of normal granulocytes that had multiple pseudopodia and microvilli. We have provided data that demonstrate that rat PAM treated with the $P$. cepacia lipase show significantly less spreading than do normal macrophages incubated in DMEMS alone. These drastic effects on the cell surface of the rat PAM could explain the reduction in their phagocytic capability, since the early stages of phago-

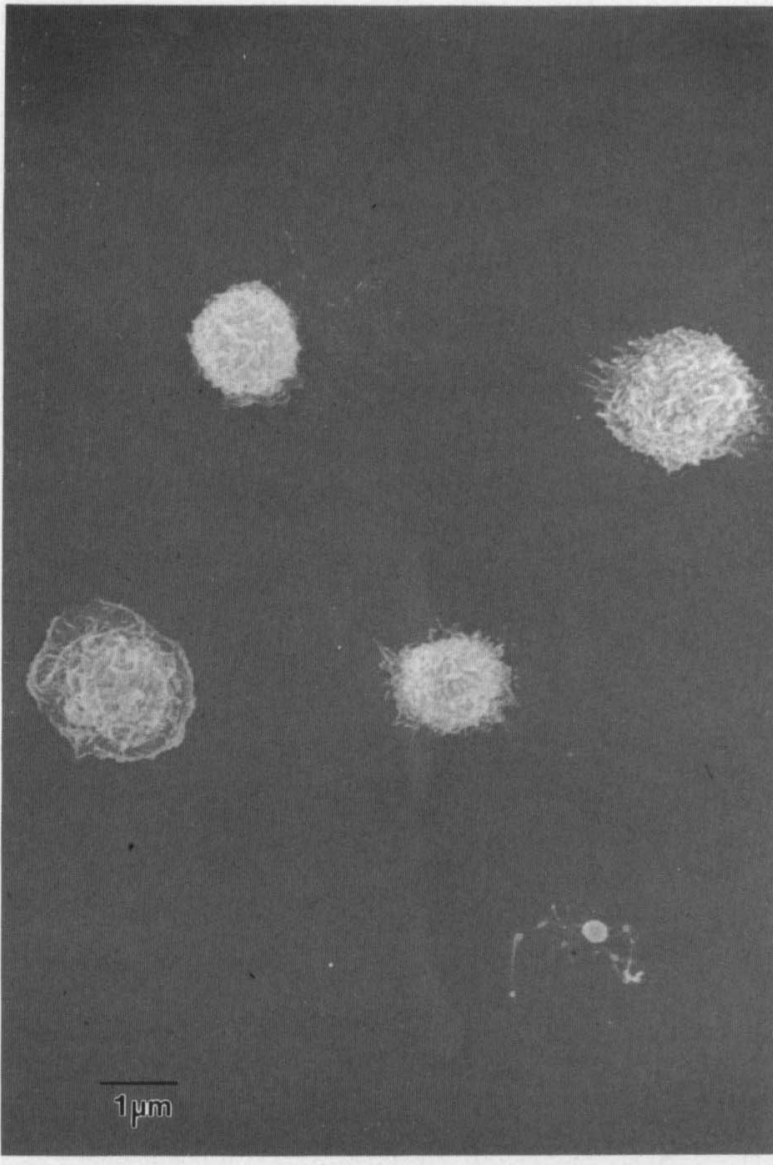

Fig. 5. SEM of rat PAM incubated for $30 \mathrm{~min}$ in DMEM plus $P$. cepacia 90ee lipase $20 \mu \mathrm{g} / \mathrm{ml}$.

cytosis involve the envestment of the bacterium with cytoplasmic processes. These effects appear to be elicited by the enzymic activity of the lipase because heat denaturation of the lipase completely negated its ability to effect these changes.

In conclusion, $P$. cepacia lipase appears to act directly on rat PAM causing changes in surface morphology and a reduction in their phagocytic capability. Our electronmicrographs demonstrate surface changes in the phagocytic cells which appear to result from the enzymic activity of $P$. cepacia lipase. These results suggest that bacterial lipases may be important virulence factors allowing bacteria to evade the mammalian host defence system.

Table. Effect of lipase treatment on PAM morphology

\begin{tabular}{|c|c|c|c|c|}
\hline \multirow[b]{2}{*}{ Morphology } & \multicolumn{2}{|c|}{ Control PAM } & \multicolumn{2}{|c|}{ Lipase-treated PAM } \\
\hline & $\begin{array}{l}\text { Number of } \\
\text { cells examined }\end{array}$ & $\begin{array}{l}\text { Average (SD) } \\
\text { number/field }\end{array}$ & $\begin{array}{l}\text { Number of } \\
\text { cells examined }\end{array}$ & $\begin{array}{l}\text { Average (SD) } \\
\text { number/field }\end{array}$ \\
\hline $\begin{array}{l}\text { Rounded } \\
\text { Spreading } \\
\text { Total }\end{array}$ & $\begin{array}{r}74 \\
134 \\
208\end{array}$ & $\begin{array}{r}3.7(1.56) \\
6.7(2.49) \\
10.4(2.87)\end{array}$ & $\begin{array}{r}64 \\
36 \\
100\end{array}$ & $\begin{array}{l}3.2(2.76) \\
1.8(1.88) \\
5\end{array}$ \\
\hline
\end{tabular}

Treatment was $20 \mu \mathrm{g} / \mathrm{ml}$ for $30 \mathrm{~min}$ at $37^{\circ} \mathrm{C}$. The beginning of pseudopodia formation was considered "spreading". The Mann-Whitney two-sample test was used to compare spreading cells with the total cell population for control versus lipase-treated PAM. There was significantly less spreading $(p=0.0001)$ of lipase-treated cells. 
This work was supported by a Biomedical Research grant from Texas Tech University Health Sciences Center and in part by a grant from the National Institute of Child Health and Human De-

\section{References}

1. Burkholder WH. Sour skin, a bacterial rot of onion bulbs. Phytopathology 1950; 40: 115-117.

2. Phillips I, Eykyn S, Curtis MA, Snell JJS. Pseudomonas cepacia (multivorans) septicemia in an intensive-care unit. Lancet 1971; 1: 375-377.

3. Speller DCE, Stephens ME, Viant AC. Hospital infections by Pseudomonas cepacia. Lancet 1971; 1: 798-799.

4. Corey M, Allison L, Prober C, Levison H. Sputum bacteriology in patients with cystic fibrosis in a Toronto hospital during 1970-1981. J Infect Dis 1984; 149: 283.

5. Isles A, Maclusky I, Corey $M$ et al. Pseudomonas cepacia infection in cystic fibrosis: an emerging problem. $J$ Pediatr 1984; 104: 206-210.

6. Thomassen MJ, Demko CA, Klinger JD, Stern RC. Pseudomonas cepacia colonization among patients with cystic fibrosis. Am Rev Respir Dis 1985; 131: 791-796.

7. McKevitt AI, Woods DE. Characterization of Pseudomonas cepacia isolates from patients with cystic fibrosis. J Clin Microbiol 1984; 19: 291-293.

8. Straus DC, Lonon MK, Woods DE, Garner CW. Production of velopment (HD2 6733 to J.C.H.). We thank D. J. Hentges for his critical review of this manuscript and Lorie Stewart for technical assistance.

an extracellular toxic complex by various strains of Pseudomonas cepacia. J Med Microbiol 1989; 30: 17-22.

9. Straus, DC, Woods DE, Lonon MK, Garner CW. The importance of extracellular antigens in Pseudomonas cepacia infections. J Med Microbiol 1988; 26: 269-280.

10. Lonon MK, Woods DE, Straus DC. Production of lipase by clinical isolates of Pseudomonas cepacia. J Clin Microbiol $1988 ; 26$ : 979-984.

11. Lonon MK, Woods DE, Straus DC. Evidence that all strains of Pseudomonas cepacia produce an immunologically similar lipase. Infect Immun (Life Sci Adv) 1990; 9: 65-74.

12. Rollof J, Braconier JH, Söderström C, Nilsson-Ehle P. Interference of Staphylococcus aureus lipase with human granulocyte function. Eur J Clin Microbiol Infect Dis 1988; 7: 505-510.

13. Hutson JC. The effects of various hormones on the surface morphology of testicular cells in culture. Am J Anat 1978; $151: 55-69$.

14. Jaeger K-E, Kharazmi A, Høiby N. Extracellular lipase of Pseudomonas aeruginosa: biochemical characterization and effect on human neutrophil and monocyte function in vitro. Microb Pathog 1991; 10: 173-182. 